\title{
Radiographic Analysis and Prevalence of Impacted Maxillary Canine Teeth in Children Between 8 and 16 Years
}

\author{
Análisis Radiográfico y Prevalencia de Caninos \\ Maxilares Retenidos en Niños entre 8 y 16 años
}

\author{
Betty Bizcar Mercado ${ }^{*, * *}$; Paulo Sandoval Vidal ${ }^{1+,+* t}$ \& Pablo Navarro Cáceres*
}

BIZCAR, M. B.; SANDOVAL, V. P. \& NAVARRO, C. P. Radiographic analysis and prevalence of impacted maxillary canine teeth in children between 8 and 16 years. Int. J. Odontostomat., 9(2):283-287, 2015.

ABSTRACT: The objective of this study was to determine the prevalence of impacted maxillary canines and analyze variables associated with its retention in panoramic radiographs. Manual and Retrospective observational study of 16,835 records. A sample of 1,353 panoramic radiographs was obtained. The variables measured were canine angle, distance from the canine apex to occlusal plane, vertical and horizontal canine location. For reliable measurement an intra class Fleiss and Cohen correlation coefficient was used (0.997). Prevalence was $2.3 \%$. 31 subjects had one or both retained canines. Average age $10.77 \pm 2.45,61.3 \%$ were women. $64.5 \%$ presented unilateral retaining of which the largest percentage was left. A total of 41 retained canines were observed. Distance to occlusal plane $19 \mathrm{~mm}$ on average. In relation to the vertical location the highest percentage (48.7\%) was found in the apical third. Regarding the horizontal location the highest percentage $(77.6 \%)$ was found in sectors 1,2 and 3 . When analyzing the canine angle it was found that $83 \%$ measured 31 degrees or more. Radicular resorption was observed in 2 lateral incisors. The prevalence found is similar to that reported in the international literature. It occurred more frequently in women and left unilateral both not statistically significant.

KEY WORDS: impacted, tooth, unerupted teeth, canine, prevalence study.

\section{INTRODUCTION}

Dental retention is considered a tooth with significant delayed eruption or clinical and radiographic signs of uneruption. Canines have a high retention rate surpassed only by third molars. Its prevalence goes from 1 to $3 \%$ (Grover \& Lorton, 1985) with twice the frequency in women and slight left unilaterality. No work has been reported in international literature related to the prevalence in Chile, so the goal is to determine the prevalence, using a radiographic analysis of impacted canines, in patients treated at the Faculty of Dentistry, Universidad de La Frontera.

Canine retention is related to its position in the bone. The panoramic radiograph can show the position and predict eruption pathway based on different measurements (Erickson \& Kurol, 1988) reservation of the canine is fundamental for being the strongest hemi-arch tooth, it occupies a strategic place of transition between the anterior and posterior area, having an aesthetic function giving harmony to the anterior face and in dental occlusion it guides laterality movements. An early diagnosis reduces treatment time, costs, complexity and potential complications such as ankylosis of the canine, cysts, infections and most importantly radicular resorption of adjacent teeth especially lateral incisor threatening its survival rate.

\section{MATERIAL AND METHOD}

We reviewed 16,835 records manually, general population who received dental care at the Faculty of Dentistry at the Universidad de La Frontera between 2005 and 2012, from which 11,983 were excluded for

\footnotetext{
Programa de Magister en Odontología, Facultad de Odontología, Universidad de La Frontera, Temuco Chile.

" Diplomado de Ortodoncia Preventiva e Interceptiva Infantil, Facultad de Odontología, Universidad de La Frontera, Temuco, Chile.

*** Magister en Educación. Especialista en Ortodoncia y Ortopedia DentoMaxiloFacial. Director Programa de Especialización en Ortodoncia y Ortopedia DentoMaxiloFacial, Universidad de La Frontera, Temuco, Chile.
} 
being over 16 years and 610 for being less than 8 years, leaving 4,242 records aged 8 to 16 years. Of these 1,353 with access to panoramic radiographs; to obtain the sample it was considered as "impacted maxillary canine" anyone who had tooth crown in intraosseous position and with complete root formation or the root apical third incomplete, but with a larger canine angle to $31^{\circ}$ as reported on Power and Short, leaving a final sample of thirty-one records with panoramic radiography where it was possible to observe one or both upper impacted canines where finally the radiographic analysis was performed.

All radiographs were taken with a Panoramic Radiograph (Proline CC, Planmeca, Helsinki, Finland). Conventional radiographic plates were used trademark Kodak T-MAT G/RA and revealing machine (XR 24 Pro, Dürr Dental AG, Bietigheim-Bissingen, Germany).

This project was approved by the Ethics Committee of the Universidad de La Frontera. The general findings of records and panoramic radiographs were managed according to ethical principles, safeguarding the confidentiality of sensitive data.

The measurements were performed directly on panoramic radiographs by a single operator, which was calibrated by an expert orthodontist. For calibration intraoperator 10 random radiographs were taken which were measured twice with a week difference between both. The intra class correlation coefficient (ICC) Fleiss was used to quantify the reliability of the measurements (Fleiss \& Cohen, 1973). The strength of concordance obtained was ICC 0.997 $(>0.90$ very good). The materials used for measurements were acetate paper for plotted negatoscope, pencil lead chuck $0.5 \mathrm{~mm}$ and Goniometer (BaselineTM CE Diagnostic and Measuring Instruments).

Horizontal location of the impacted canine was measured using the sectoral method of Ericson \& Kurol (1987) and modified by Lindauer et al. (1992) (Fig. 1). Vertical location (Fig. 2) and canine angle was measured according to that described by Power \& Short (1993) (Fig. $3)$. And the distance from the apex of the impacted canine to occlusal plane was measured in relation to that described by Ericson \& Kurol (1987) (Fig. 3).

To collect data a spreadsheet was designed in Microsoft Office Excel 2010, for further statistical analysis (IBM SPSS Statistics for Windows version 20.0, IBM Corp., Armonk, NY). Chi Square test of Pearson, Fisher exact test and $t$ test for independent samples were performed. A value of $p<0.05$ was chosen as the threshold for statistical significance.

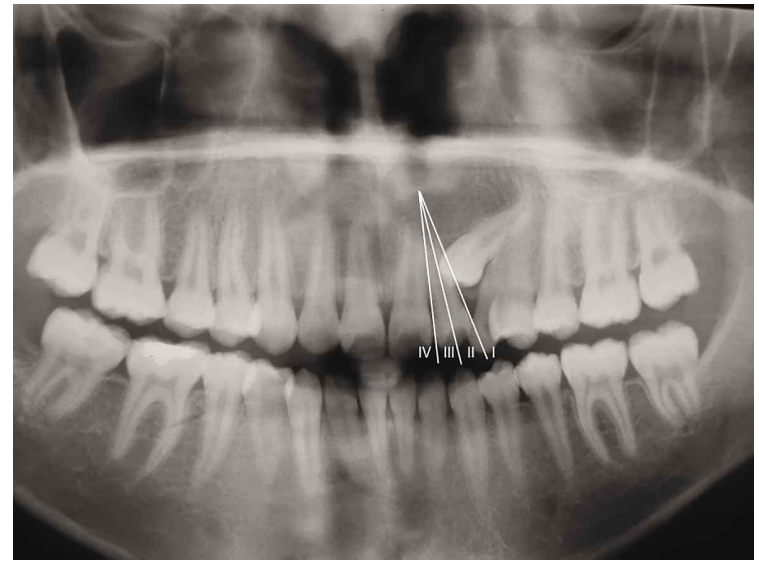

Fig. 1. Horizontal location of impacted canine. (I) Distal lateral incisor; (II) between distal and half of lateral incisor; (III) between mesial and middle lateral incisor and (IV) mesial of the lateral incisor.

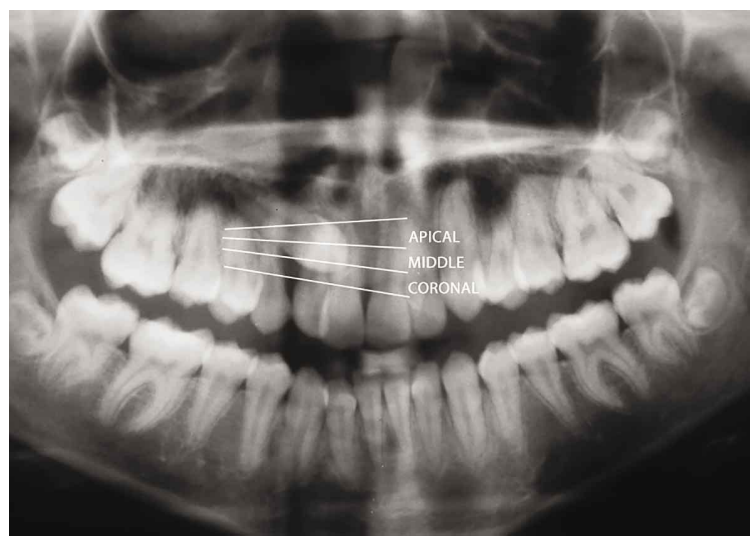

Fig. 2. Vertical location of impacted canine. Layout of four lines that divide the roots of the lateral incisors and Central into three equal spaces. (A) Apical Third; (M) middle third; $(C)$ coronal third. The space was assigned in relation to the location of the peak of the canine.

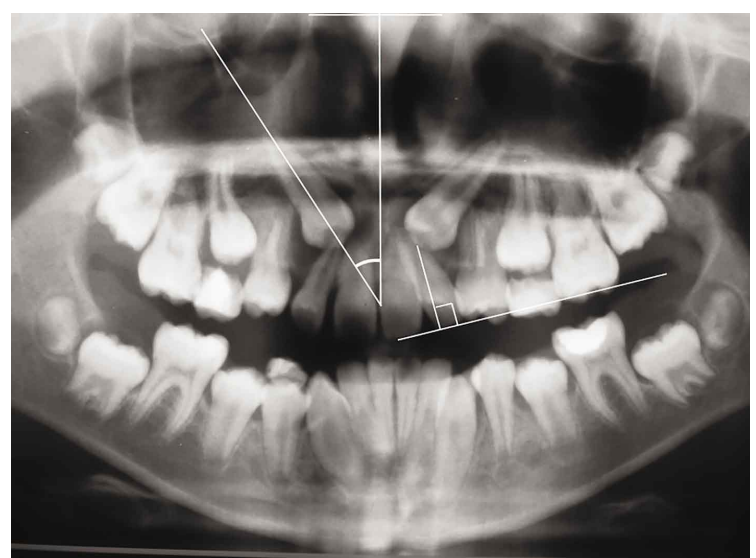

Fig. 3. Canine angle of the canine. Binding of longitudinal axis of the canine and a mean line through the anterior nasal spine and perpendicular to the upper edge of the radiograph. Distance to occlusal plane, straight line extending from the tip of the canine apex to contact perpendicularly to the occlusal plane. 


\section{RESULTS}

The prevalence was $2.3 \%$ overall child population. 31 subjects had one or both impacted canines. Average age was $10.77 \pm 2.45$ years; $61.3 \%$ were women. $35.5 \%$ (11 subjects) presented bilateral canine retaining, $64,5 \%$ (20 subjects) presented unilateral retaining, of which $29 \%$ (9 subjects) was only right side and $35.5 \%$ (11 subjects) only the left side, obtaining a total of 41 impacted canines. Distance to occlusal plane $19 \mathrm{~mm}$ on average. In relation to the vertical location at the highest percentage of canine teeth retained $(48.7 \%)$ was found in the apical third (Table I). Relative to the horizontal location the higher percentage $(77.6 \%)$ was found in the sectors 1, 2 and 3 (Table II). When analyzing the canine angle it was found that $83 \%$ measured 31 degrees or more (Table III). Root resorption of 2 lateral incisors as a result of canine adjacent retention was observed, this resorption was observed in the root apical third. None of the measured variables were statistically significant.

Table I. Distribution of impacted maxillary canine teeth retained relative to its vertical location.

\begin{tabular}{lcccc}
\hline & Apical third & Middle third & Coronal third & Total \\
\hline Frequency & 20 & 13 & 8 & 41 \\
Percentage & $48.7 \%$ & $31.7 \%$ & $19.5 \%$ & $100 \%$
\end{tabular}

Table II. Distribution of impacted maxillary canine teeth retained in relation to its horizontal location.

\begin{tabular}{lccccc}
\hline & Sector $\mathbf{1}$ & Sector $\mathbf{2}$ & Sector $\mathbf{3}$ & Sector $\mathbf{4}$ & Total \\
\cline { 2 - 6 } Frequency & 20 & 6 & 7 & 8 & 41 \\
Percentage & $47.6 \%$ & $14.3 \%$ & $16.7 \%$ & $21.4 \%$ & $100 \%$ \\
\hline
\end{tabular}

Table III. Distribution of maxillary canines relative to the size of canine angle.

\begin{tabular}{lcccccc}
\hline & $\mathbf{1 0}^{\circ}-\mathbf{2 0 ^ { \circ }}$ & $\mathbf{2 1}^{\circ}-\mathbf{3 0 ^ { \circ }}$ & $\mathbf{3 1}^{\circ}-\mathbf{4 0}^{\circ}$ & $\mathbf{4 1}^{\circ}-\mathbf{5 0 ^ { \circ }}$ & $\mathbf{5 1}^{\circ}-\mathbf{6 0}^{\circ}$ & Total \\
\cline { 2 - 7 } Frequency & 2 & 5 & 23 & 7 & 4 & 41 \\
Percentage of total & $4.8 \%$ & $12.2 \%$ & $56.1 \%$ & $17.1 \%$ & $9.8 \%$ & $100 \%$ \\
\hline
\end{tabular}

\section{DISCUSSION}

Determined by radiographic analysis, the prevalence of impacted canines and factors associated with their retention in patients between 8 and 16 years treated at the Faculty of Dentistry of the Universidad de La Frontera, were the main objectives of this study.

The prevalence of this study $(2.3 \%)$ was found to be similar to that reported in the international literature on epidemiological studies in European general population ranging from 1-3\% (Peck et al., 1994). However it is lower than that reported by Aydin et al. (2004) who found a $3.29 \%$ in a population of Turkey and found by Patil \& Maheshwari (2014) which was $9.7 \%$ in India.
When observing the prevalence of orthodontic patients from these consultations were also higher to those found in our study in Mexico (Güere Rochebaum \& Silva Meza, 2013), observed a canine retaining of $5.3 \%$ (Becker et al., 1981), reported a prevalence of $13.9 \%$ (Lempesi et al., 2014) obtained $5.6 \%$ of canine retaining.

According to sex in this study was observed more frequently (not statistically significant) in women, coinciding with those reported by other authors, as Nieri et al. (2010), Becker et al., Lempesi et al., who reported in their studies a higher retention in women. 
In this study canine retaining occurred more frequently unilaterally that bilateral, predominantly on the left side, being this distribution similar to that found by Becker et al., who reported higher unilateral percentage $(54.6 \%)$ than bilateral $(45.4 \%)$. Lempesi et al. report an unilaterality of $65.7 \%$ of cases as in all studies analyzed in Peck et al., unilateral retaining was higher; Stewart et al. (2001) found 61\% of unilateral and bilateral $38.3 \%$, but unlike our study they found higher percentage $(50.8 \%)$ of retaining at the right side.

When analyzing horizontal location of the impacted canines of our population the highest percentage stood at sectors I, II and III being similar that found by Jung et al. (2012) in children under 15 years (Warford et al., 2003; Lindauer et al.).

Regarding the mesial angulation of canine, our study found that $83 \%$ of cases measured 31 degrees or more which coincides with the findings of Sajnani \& King (2012) that was 30 degrees, this could be related to canines rooted in formation, which to be included in the study had to have an angle of 31 degrees or more. Differing from that found by Stewart et al., who reported a low percentage $(35.4 \%)$ of cases with higher angle than 35 degrees. In Nieri et al., the average size of the canine angle was 36 degrees similar to ours that was 36.2 degrees, a standard deviation of 10.29 degrees with a minimum of 10.5 to a maximum of 69 degrees.

In this study distance to occlusal plane on average was $19 \mathrm{~mm}$ which is similar to that reported by Sajnani \& King that was $18.2 \mathrm{~mm}$ and Nieri et al., which was $15 \mathrm{~mm}$.

In relation to resorption of lateral incisors this occurred in $4.7 \%$ of subjects resulting in a prevalence of $0.1 \%$, in contrast to what was found by Ericson \& Kurol (1987) that was $12 \%$ of cases with a prevalence of $0.7 \%$ and from the study of Schindel \& Sheinis (2013) in which root resorption of lateral incisors was $21.8 \%$.

\section{CONCLUSION}

The prevalence found is similar to that reported in the international literature. It occurred more frequently in women, unilaterally, with a slight preference for the left side. The canine angle was located more frequently in the sectors I, II and III; All these variables were not statistically significant.
BIZCAR, M. B.; SANDOVAL, V. P. \& NAVARRO, C. P. Análisis radiográfico y prevalencia de caninos maxilares retenidos en niños entre 8 y 16 años. Int. J. Odontostomat., 9(2):283-287, 2015.

RESUMEN: El objetivo de este trabajo fue determinar la prevalencia de dientes caninos maxilares retenidos y analizar variables asociadas a su retención, en radiografías panorámicas. Se realizó un estudio observacional retrospectivo y manual de 16.835 fichas. Se obtuvo una muestra de 1.353 radiografías panorámicas. Las variables medidas fueron ángulo del canino, distancia de la cúspide del canino al plano oclusal, localización vertical y horizontal del canino. Para la fiabilidad de las mediciones se usó el coeficiente de correlación intraclase de Fleiss \& Cohen $(0,997)$. La prevalencia fue $2,3 \%$. Treinta y un sujetos presentaron 10 ambos caninos retenidos. La edad promedio fue $10,77 \pm 2,45$, y el $61,3 \%$ fueron mujeres. El 64,5\% presentó retención unilateral, principalmente del lado izquierdo. Se observó un total de 41 caninos retenidos. La distancia al plano oclusal en promedio fue $19 \mathrm{~mm}$. En relación a la localización vertical, el mayor porcentaje $(48,7 \%)$ se encontró en el tercio apical. Respecto a la localización horizontal, el mayor porcentaje $(77,6 \%)$ se encontró en los sectores 1,2 y 3 . Al analizar el ángulo canino, se encontró que $83 \%$ midió $31^{\circ}$ o más. Se observó reabsorción radicular de dos incisivos laterales. La prevalencia encontrada es similar a la reportada en la literatura internacional. La retención se presentó con mayor frecuencia en mujeres y de manera unilateral en el lado izquierdo, pero en ambos casos no es significativa.

PALABRAS CLAVE: diente retenido, diente no erupcionado, canino, prevalencia.

\section{REFERENCES}

Aydin, U.; Yilmaz, H. H. \& Yildirim, D. Incidence of canine impaction and transmigration in a patient population. Dentomaxillofac. Radiol., 33(3):164-9, 2004.

Becker, A.; Smith, P. \& Behar, R. The incidence of anomalous maxillary lateral incisors in relation to palatally-displaced cuspids. Angle Orthod., 51(1):24-9, 1981.

Ericson, S. \& Kurol, J. Radiographic examination of ectopically erupting maxillary canines. Am. J. Orthod. Dentofacial Orthop., 91(6):483-92,1987.

Ericson, S. \& Kurol, J. Resorption of maxillary lateral incisors caused by ectopic eruption of the canines. A clinical and radiographic analysis of predisposing factors. Am. J. Orthod. Dentofacial Orthop., 94(6):503-13, 1988.

Fleiss, J. L. \& Cohen, J. The equivalence of weighted kappa and the intraclass correlation coefficient as measures of reliability. Educ. Psychol. Meas., 33:613-9, 1973. 
Grover, P. S. \& Lorton, L. The incidence of unerupted permanent teeth and related clinical cases. Oral Surg. Oral Med. Oral Pathol., 59(4):420-5, 1985.

Güere Rochebaum, I. \& Silva Meza, R. Evaluación radiográfica de caninos maxilares impactados, en una muestra de una población mexicana. Rev. Latinoam. Ortod. Odontopediatr., 2013. Available from: https:// www.ortodoncia.ws/publicaciones/2013/art7.asp

Jung, Y. H.; Liang, H.; Benson, B. W.; Flint, D. J. \& Cho, B. $H$. The assessment of impacted maxillary canine position with panoramic radiography and cone beam CT. Dentomaxillofac. Radiol., 41(5):356-60, 2012.

Lempesi, E.; Karamolegkou, M.; Pandis, N. \& Mavragani, M. Maxillary canine impaction in orthodontic patients with and without agenesis: a cross-sectional radiographic study. Angle Orthod., 84(1):11-7, 2014.

Lindauer, S. J.; Rubenstein, L. K.; Hang, W. M.; Andersen, W. C. \& Isaacson, R. J. Canine impaction identified early with panoramic radiographs. J. Am. Dent. Assoc., 123(3):91-2, 95-7, 1992.

Nieri, M.; Crescini, A.; Rotundo, R.; Baccetti, T.; Cortellini, P. \& Pini Prato, G. P. Factors affecting the clinical approach to impacted maxillary canines: A Bayesian network analysis. Am. J. Orthod. Dentofacial Orthop., 137(6):75562, 2010

Patil, S. \& Maheshwari, S. Prevalence of impacted and supernumerary teeth in the North Indian population. $J$. Clin. Exp. Dent., 6(2):e116-20, 2014.

Peck, S.; Peck, L. \& Kataja, M. The palatally displaced canine as a dental anomaly of genetic origin. Angle Orthod., 64(4):249-56, 1994.

Power, S. M. \& Short, M. B. An investigation into the response of palatally displaced canines to the removal of deciduous canines and an assessment of factors contributing to favourable eruption. Br. J. Orthod., 20(3):215-23, 1993.

Sajnani, A. K. \& King, N. M. Early prediction of maxillary canine impaction from panoramic radiographs. Am. J. Orthod. Dentofacial Orthop., 142(1):45-51, 2012.

Schindel, R. H. \& Sheinis, M. R. Prediction of maxillary lateral-incisor root resorption using sector analysis of potentially impacted canines. J. Clin. Orthod., 47(8):490$3,2013$.

Stewart, J. A.; Heo, G.; Glover, K. E.; Williamson, P. C.; Lam, E. W. \& Major, P. W. Factors that relate to treatment duration for patients with palatally impacted maxillary canines. Am. J. Orthod. Dentofacial Orthop., 119(3):21625, 2001.
Warford, J. H. Jr.; Grandhi, R. K. \& Tira, D. E. Prediction of maxillary canine impaction using sectors and angular measurement. Am. J. Orthod. Dentofacial Orthop., 124(6):651-5, 2003.

Dirección para Correspondencia:

Prof. Paulo Sandoval Vidal

Departamento de Odontopediatría y Ortodoncia

Facultad de Odontología

Universidad de La Frontera

Manuel Montt 115

Temuco

CHILE

Email: paulo.sandoval@ufrontera.cl

Recibido : 02-05-2015

Aceptado: 03-06-2015 